\title{
Pigmented fungiform papillae of the tongue: Co-existence of two patterns in the same patient and associated dental pigmentation
}

\author{
Dilde pigmente fungiform papilla: Iki paternin birlikteliği ve eșlik eden diș
}

pigmentasyonu

\section{Ayșe Kavak, ๑ Zeynep Topkarcı, ๑ Emine Erișmen Gür, ๑ Bilgen Erdoğan, ๑ Ayșe Yemișçi}

University of Health Sciences Turkey, Bakırköy Dr. Sadi Konuk Training and Research Hospital, Clinic of Dermatology, Istanbul, Turkey

\begin{abstract}
This report presents a case of pigmented fungiform papillae of the tongue (PFPT) in a 12-year-old girl. She had type 1 and 2 PFPT. Diffuse, patchy tongue pigmentation seen in our patient might be a racial pigmentation or a component of PFPT. We also discussed whether the associated dental pigmentation could be an incidental finding or chromogenic bacteria or previous oral iron treatment might have a role in PFPT.

Keywords: Fungiform papillae, pigmented, teeth, tongue
\end{abstract}

Öz

Dilde pigmente fungiform papilla (DPFP) saptanan 12 yaşındaki bir kız çocuğunda, tip 1 ve 2 paternlerinin birlikteliği gözlendi. Dilde eşlik eden difüz, yama tarzındaki pigmentasyonun, ırksal bir pigmentasyon ya da DPFP'nin bir komponenti olabileceği düşünüldü. Bu hastanın bir diğer ilginç özelliği ise dişlerdeki pigmentasyon idi. Bu durum, rastlantısal olabileceği gibi, kromojenik bakteriler ya da önceki oral demir tedavisine bağlı olabilir.

Anahtar Kelimeler: Fungiform papilla, pigmente, diş, dil

\section{Introduction}

Pigmented fungiform papillae of the tongue (PFPT) is usually seen in women with Fitzpatrick skin types $4-6^{1,2}$. PFPT has been reported rarely possibly due to the underreporting of cases $^{1,2}$.

Three types of PFPT were described. Type 1 is a well-defined hyperpigmented macule, in which all the fungiform papillae were involved and located at the anterolateral surface or tip of the tongue. Type 2 is characterized by hyperpigmentation involving 3-7 papillae that are randomly distributed at the dorsal surface of the tongue. Type 3 is described as hyperpigmentation of all fungiform papillae at the dorsal surface of the tongue ${ }^{1}$. Co-occurrence of two PFPT types in the same individual has been rarely reported ${ }^{3}$.

\section{Case Report}

A 12-year-old girl with skin type 4 was referred to an oral mucosa clinic for a complaint of asymptomatic lesion on her tongue of 5 months duration. Her medical and family histories were unremarkable. She denied smoking or current use of any medication. She had a past medical history of iron deficiency anemia, which was treated with oral iron (II)glycin-sulfate complex 2 years ago.

Dermatologic examination revealed asymptomatic, brown individual pigmentations of the fungiform papillae. Fungiform papilla pigmentation in the right side had a grouped pattern consistent with type 1 PFPT, while a scattered pattern was observed in the left side (type 2) (Figure 1). Diffuse graybrown pigmented patches were also scattered on the

Address for Correspondence/Yazıșma Adresi: Ayşe Kavak MD, Acıbadem Mehmet Ali Aydınlar University, Atakent Hospital, Department of Dermatology, istanbul, Turkey Phone: +90 5323616264 E-mail: ayse.kavak1@gmail.com

Received/Geliş Tarihi: 08.08.2018 Accepted/Kabul Tarihi: 07.11.2020 ORCID: orcid.org/0000-0002-4679-1181

CCopyright 2021 by Turkish Society of Dermatology and Venereology

Turkderm - Turkish Archives of Dermatology and Venereology published by Galenos Yayınevi. 
middle and lateral parts of the dorsal tongue (Figure 2). Additionally, dark-brown pigmentations were noted in some teeth adjacent to the pigmented fungiform papillae (Figure 3). Dermatologic examination findings, including the nails and genital area, were normal. Dermoscopy findings were consistent with both "cobblestone" and "rose petal" patterns (Figure 4).

Dentistry consultation showed that dental pigmentation could be due to chromogenic bacteria commonly seen in these age groups. Complete blood count, comprehensive metabolic panel, iron panel, and thyroid function tests were within normal limits. Informed consent was obtained.

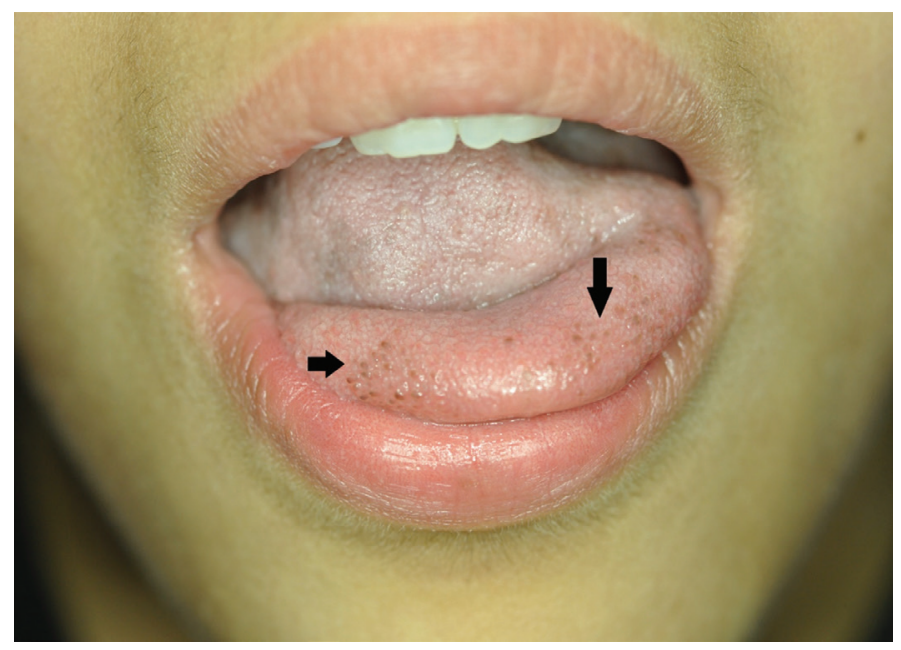

Figure 1. Type 1 (right anterior, $\Rightarrow$ ) and type 2 (left anterior, $\mathbf{l}$ ) PFPT PFPT: Pigmented fungiform papillae of the tongue

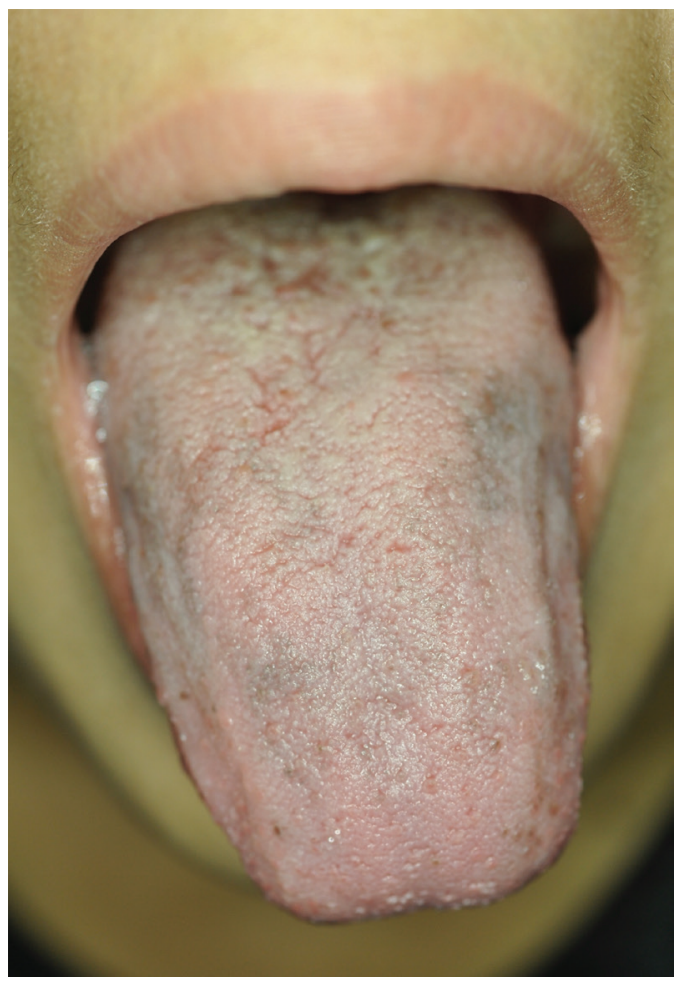

Figure 2. Gray-brown, patchy diffuse pigmentation in the middle part of the tongue

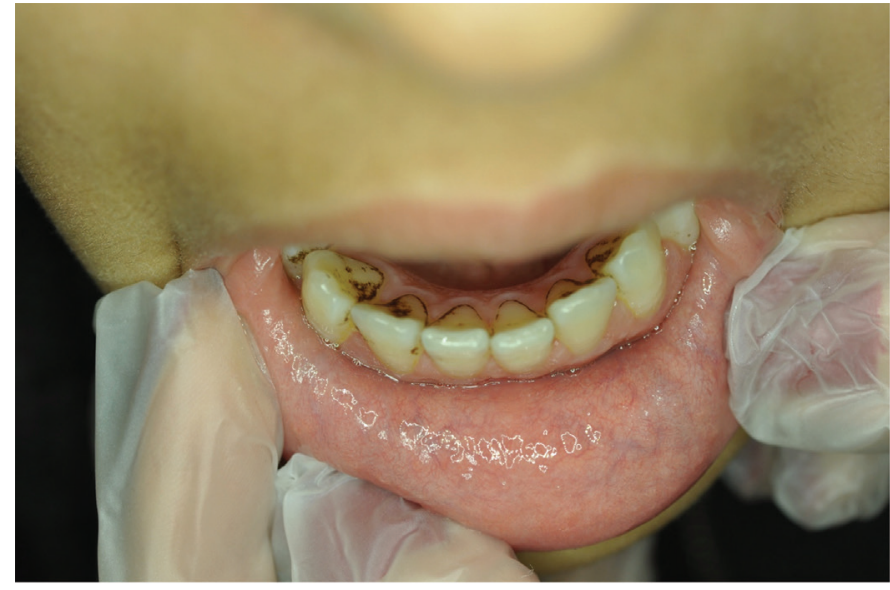

Figure 3. Pigmentation of the anterior teeth

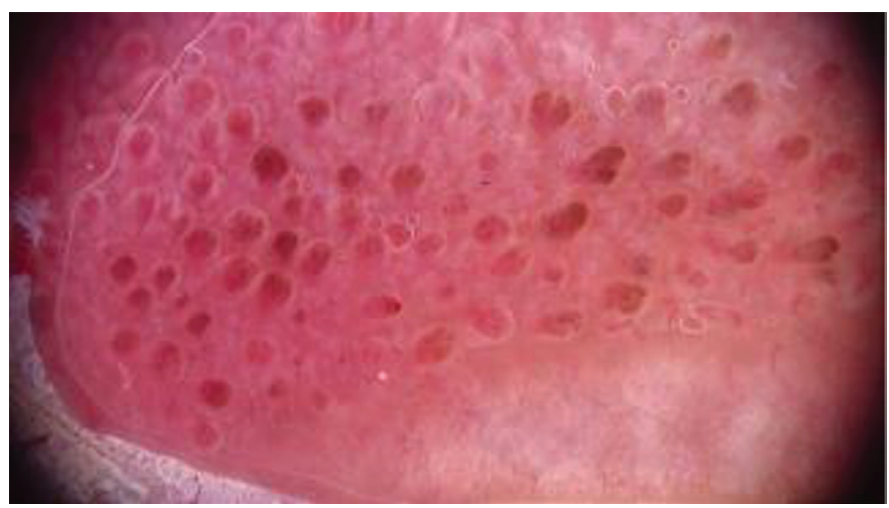

Figure 4. Dermoscopy showed both patterns

\section{Discussion}

Holzwanger et al. ${ }^{1}$ described three types of PFPT. Overlap between types 1 and 2 has been reported rarely ${ }^{3}$. The presented case showed type 1 and 2 PFPT on the right and left sides of the anterior tongue, respectively. Distinct from PFPT features, predominant gray-pigmented patches were observed in the middle and lateral parts of the dorsum of the tongue in our patient. Since the pigmentation was not limited to the filiform PFPT, it might be considered as a racial feature or a separate finding associated with PFPT.

"Cobblestone" and "rose petal" patterns are characteristic dermoscopic findings in $\mathrm{PFPT}^{3,4}$. A cobblestone pattern is characterized with brownish discrete polygonal globules confined to the fungiform papillae, resembling a "cobblestone"2. A rose petal pattern has been defined as projections with pigmented borders, interspersed with dichotomized vessels that originated in its base, with aspect resembling "rose petals" 4 . Sometimes it is difficult to determine a strict single pattern particularly for some rare entities. Our patient showed both "cobblestone" and "rose petal" patterns.

Black teeth in children may be caused by some drugs, foods, and drinks, as well as decay and chromogenic bacteria. Pigmentation of the teeth in the neighboring PFPT area is questionable as it is still unknown whether this is an incidental finding or a part of this entity. Although pigmentations of the nails ${ }^{3}$, gingiva ${ }^{3}$, and skin (co-existence with melasma) ${ }^{2}$ have been reported, dental pigmentation is not a well-known component of PFPT. In our case, neither the patient nor 
her family was aware of the dental pigmentation. Even though an association between teeth discoloration and iron supplement intake is well known ${ }^{5}$, in our case, we did not have enough data to conclude or exclude the association. In the present case, the patient had a history of iron supplement intake $\sim 2$ years ago. Unfortunately, we were unable to find any reports supporting the long-term effect of iron supplement intake on dental discoloration. The association of tongue and dental pigmentation supports the hypothesis of chromogenic bacteria or oral iron treatment as the cause. However, more data are needed to verify this hypothesis.

Although PFPT is usually seen as an isolated entity, it may be associated with hemochromatosis, chronic active hepatitis, Hori's nevus, and melasma ${ }^{2,6}$. Additionally, co-existence of iron deficiency anemia has been reported as in our patient ${ }^{7}$. Black hairy tongue, Addison's disease, and melanoma are some of the diseases to consider in the differential diagnosis. However, typical clinical findings together with supporting dermoscopic features help the diagnosis of PFPT. Although amalgam is a frequent cause of lingual pigmentation, it has a different pattern. PFPT is an oral pseudopathology. The combination (or overlap) of different types have been rarely reported in the same patient. Coexistence of lingual and dental pigmentation could be either an incidental finding or a component of PFPT. These additional findings might have been underreported due to subtle characteristics. Further case studies are needed to reveal whether these findings are coincidental or have a role in the pathogenesis of PFPT.

Acknowledgments: We thank Dt. Ayşegül Evliyaoğlu and Dt. Asim Dumlu for dentistry consultation. We also thank Nazila Barahmani, MD., for English assistance.

\section{Ethics}

Informed Consent: It was obtained.
Peer-review: Externally peer-reviewed.

\section{Authorship Contributions}

Surgical and Medical Practices: A.K., Z.T., Concept: A.K., Z.T., B.E., E.E.G., A.Y., Design: A.K., Z.T., Data Collection or Processing: Z.T., Analysis or Interpretation: A.K., Literature Search: B.E., E.E.G., A.Y., Writing: A.K., Z.T.

Conflict of Interest: No conflict of interest was declared by the authors.

Financial Disclosure: The authors declared that this study received no financial support.

\section{References}

1. Holzwanger JM, Rodolph $\mathrm{RI}$, Heaton $\mathrm{CL}$ : Pigmented fungiform papillae of the tongue: a common variant of oral pigmentation. Int I Dermatol 1974;13:403-8

2. Tan C, Liu Y, Min ZS, Zhu WY: A clinical analysis of 58 chinese cases of pigmented fungiform papillae of the tongue. J Eur Acad Dermatol Venereol 2014;28:242-5

3. Chessa MA, Patrizi A, Sechi A, Virdi A, Leuzzi M, Neri I: Pigmented fungiform lingual papillae: Dermoscopic and clinical features. J Eur Acad Dermatol Venereol 2018;32:935-9.

4. Mukamal LV, Ormiga P, Ramos-E-Silva M: Dermoscopy of the pigmented fungiform papillae of the tongue. J Dermatol 2012;39:397-9.

5. Garcia Martin JM, Gonzalez Garcia M, Seoane Leston J, Llorente Pendas S, Diaz Martin JJ, Garcia-Pola MJ: Prevalence of black stain and associated risk factors in preschool Spanish children. Pediatr Int 2013;55:355-9.

6. Scarff $C E$, Marks R: Pigmented fungiform papillae on the tongue in an Asian man. Australas J Dermatol 2003;44:149-51.

7. Ahn SK, Chung J, Lee SH, Lee WS: Prominent pigmented fungiform papillae of the tongue. Cutis 1996;58:410-2. 